\title{
電荷双安定性に由来する擬一次元八ロゲン架橋金属錯体の 動的挙動創出と可視化 \\ Creation and Visualization of the Charge Dynamics in Quasi-One- Dimensional Halogen-Bridged Metal Complexes Driven by the Charge Bistability
}

\author{
東北大学大学院理学研究科 高石 慎也* \\ Department of Chemistry, Graduate School of Science, Tohoku University \\ Shinya Takaishi* \\ Received February 15, 2011; E-mail: takaishi@agnus.chem.tohoku.ac.jp
}

\begin{abstract}
Metal complexes have originally many kinds of bistability owing to charge, spin, lattice etc. Recently, there has been much effort for controlling the macroscopic properties by the molecular bistability through cooperative phenomena. In the one-dimensional systems, especially, dynamics can be expected owing to the bistability of molecules because cooperativity is not so strong comparing to three-dimensional systems. We have studied on the charge dynamics in quasione-dimensional halogen-bridged metal complexes by using charge bistability of metal ions.

In this review, a method for creating the charge bistability by reducing band gap energy and new method for detecting such a charge bistability by using scanning tunneling microscopy (STM) has been reported.
\end{abstract}

\section{1. はじめに}

金属イオンはスピンや電荷状態の多様性に起因した数 多くの双安定性を潜在的に有しており、集積化によって、 この双安定性をマクロスケールに連動させることが可能 であると考えられる。 実際に近年、この双 安定性を利用してマ クロな物性を制御し よう、という試みが 多方面でなされてい る ${ }^{1-3)}$ 。金属イオンを 一次元に集積させた 一次元集積体におい ては、相互作用が一 次元方向に限定され るため、その協同効 果が三次元系に比べ て弱く、金属イオン MMX chains.

連絡先著者名: 高石 慎也

連絡先 : 980-8578 仙台市青葉区荒巻字青葉 6-3

東北大学大学院理学研究科

Tel: 022-795-3878 Fax: 022-795-6547

Corresponding Author: Shinya Takaishi

Address: 6-3 Aza-Aoba, Aramaki, Aoba-ku, Sendai 980-8578, Japan

Keywords:one-dimensional, MX-chain, mixed valence, phase transition,

scanning tunneling microscopy, phase transition
が元来持っている摇らぎがその物性を支配することが期 待される。

以上より我々は、擬一次元ハロゲン架橋金属錯体 $(M X, M M X$ 型錯体)(Fig. 1) に着目し、同錯体に対して電 荷の双安定性を付与し、そこから生じる動的挙動を創出 することを目的として研究を行ってきた。ここでは同錯 体において、電荷の双安定性に起因する動的挙動を創出 するための試み、およびそれを観測するための測定手法 について述べる。

\section{2. 擬一次元ハロゲン架橋単核金属錯体 (MX 錯体)}

\section{1. $\mathrm{MX}$ 錯体の歴史}

MX 錯体の歴史は、19 世紀末に Wolffram が報告した $\mathrm{Cl}$ 架橋 $\mathrm{Pt}$ 錯体 $\left[\mathrm{Pt}(\mathrm{etn})_{4} \mathrm{Cl}\right] \mathrm{Cl}_{2} \cdot 2 \mathrm{H}_{2} \mathrm{O}$ (etn = aminoethane) に 端を発する (Fig. 2) ${ }^{4}$ 。ここの錯体は、金属光沢を持つ鮮 やかな赤色を呈したことから、Wolffram 赤色塩と呼ば れるようになった。当初は、組成式から $\mathrm{Pt}^{3+}$ 錯体と考 えられていたが、後に平面型の $\mathrm{Pt}^{2+}$ 錯体 $\left(\left[\mathrm{Pt}^{2+}(\mathrm{etn})_{4}\right]^{2+}\right)$ と八面体型の $\mathrm{Pt}^{4+}$ 錯体 $\left(\left[\mathrm{Pt}^{4+}(\mathrm{etn})_{4} \mathrm{Cl}_{2}\right]^{2+}\right)$ が交互に積層 した $\mathrm{Pt}^{2+}-\mathrm{Pt}^{4+}$ の混合原子価状態をとっていることが明ら かとなった ${ }^{5)}$ 。同錯体の偏光特性や電子スペクトルにつ いては、1950 年代に桘田らによって精力的に研究され、 赤色の起源が $\mathrm{Pt}^{2+}$ から $\mathrm{Pt}^{4+}$ への原子価間電荷移動 (IVCT: InterValence Charge Transfer) 遷移であると結論付けられ たの。さらに 1960 年代に入ると木田らにより MX 錯体 
の類縁体が精力的に開発さ れた ${ }^{7)}$ その後しばらく注 目されることはなかったが、 1980 年頃から光物性を中心 に再び注目を集め、高次の 共鳴ラマン散乱 ${ }^{8)}$ 、ソリト ンやポーラロンに基づくミ ッドギャップ吸収 ${ }^{9)}$ 、大き な Stokes シフトを伴う発光 など ${ }^{10)}$ 、数多くの興味深い 物性が報告されてきた。こ れに伴い物質開発も盛んに

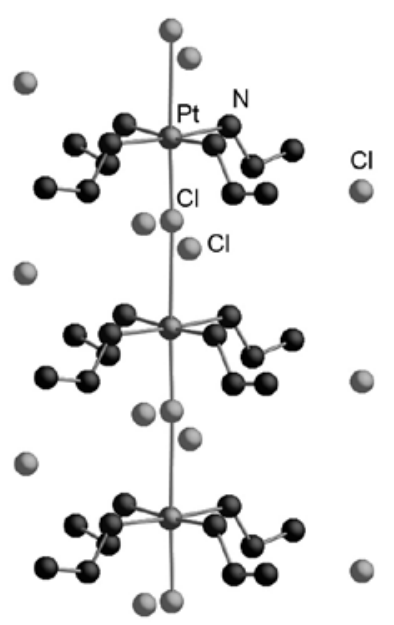

行われ始め、金属イオン (M Fig. 2 Structure of Wolffram $=\mathrm{Pt}, \mathrm{Pd})$ 、面内配位子 $(\mathrm{L}=$ red salt.

alkylamine, ethylenediamine (en), $1 R, 2 R$-diaminocyclohexane (chxn) などを多岐に組み合わせた数多くの MX 錯体が報 告された。Pd、Pt と同属の $\mathrm{Ni}$ 錯体については長らく報 告がなかったが、1981 年に山下らにより [Ni(chxn) $\left.)_{2} \mathrm{Br}\right]$ $\mathrm{Br}_{2}$ が初めて報告された ${ }^{11)}$ 。 $\mathrm{Ni}$ 錯体も当初は $\mathrm{Ni}^{2+}-\mathrm{Ni}^{4+}$ の 混合原子価状態であると考えられていたが、後にX線構 造解析の結果から架橋の臭化物イオンが $\mathrm{Ni}$ 間の中央に あり、 $\mathrm{Ni}^{3+}$ 平均原子価状態であることが明らかにされた ${ }^{12)}$ 。現在では、これらの MX 錯体について 300 種類以上 の類縁体が報告されている。

\section{2. $M X$ 錯体の電子基底状態}

これまでに報告されているすべての MX 錯体はその 電子基底状態が金属イオンに依存し、 $\mathrm{Ni}$ 錯体では平均 原子価状態 : $\left.-\mathrm{X}-\mathrm{M}^{3+}-\mathrm{X}-\mathrm{M}^{3+}-\mathrm{X}-\right)$ 、 $\mathrm{Pd}, \mathrm{Pt}$ 錯体では混合原 子価状態: $\left.-\mathrm{X} \cdots \mathrm{M}^{2+} \cdots \mathrm{X}-\mathrm{M}^{4+}-\mathrm{X} \cdots\right)$ を例外なく取ること が知られている。このように、MX 錯体で金属イオンの 種類によって電子基底状態が異なる理由は以下のように 説明される。金属イオンは、面内 $(\mathrm{x}, \mathrm{y}$ 方向)ではアミ ンの窒素原子による比較的強い配位を受けている (M-N 間距離: $2.0 \sim 2.1 \AA$ ) のに対し、軸方向 (z 方向 ) からは ハロゲン化物イオンによる弱い配位を受けている (M-X 間距離 : $2.6 \sim 3.5 \AA)$ 。そのため、金属イオン周りの配 位環境は $\mathrm{z}$ 方向に伸長した八面体構造と見なすことがで きる。金属イオンのとりうる酸化数は $\mathrm{M}^{2+}\left(\mathrm{d}^{8}\right) 、 \mathrm{M}^{3+}\left(\mathrm{d}^{7}\right)$ 、

(a)
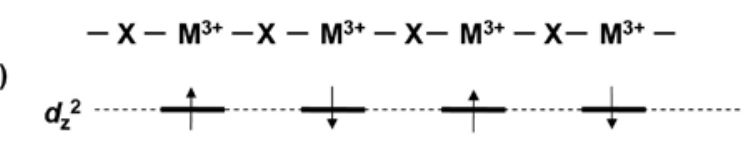

(b)

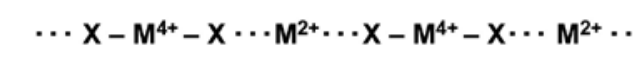

$d_{z}^{2}$

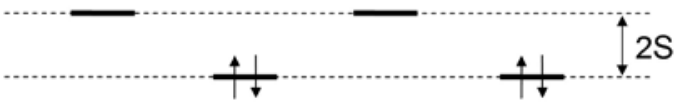

Fig. 3 Energy level diagrams of $d_{z} 2$ orbitals in averaged valence (a) and mixed valence (b) states.
$\mathrm{M}^{4+}\left(\mathrm{d}^{6}\right)$ であるため、 $\mathrm{dz}^{2}$ 軌道に収容される電子数は $\mathrm{M}^{2+}\left(\mathrm{dz}^{2}\right) 、 \mathrm{M}^{3+}\left(\mathrm{dz}^{2}\right) 、 \mathrm{M}^{4+}\left(\mathrm{dz}^{20}\right)$ となる。この軌道は、厳 密には純粋な $\mathrm{dz}^{2}$ ではなく金属イオンの $\mathrm{dz}^{2}$ 軌道と架橋 ハロゲンの $\mathrm{p}_{\mathrm{z}}$ 軌道からなる反結合性軌道であるが、本 稿では単純化して $\mathrm{dz}^{2}$ 軌道と表記することにする。した がって MX 錯体の電子状態は、 $\mathrm{N}$ 個の $\mathrm{dz}^{2}$ 軌道に $\mathrm{N}$ 個の 電子をどのように収容するかという問題に帰着する。通 常、単一の軌道に複数の電子を収容しょうとすると、電 子間の反発 $(U)$ による不安定化が生じるために、それぞ れのサイトに一電子ずつ収容した状態 (=均化状態 (Fig. 3(a))）が最安定状態となる。 $\mathrm{Ni}$ 錯体が平均原子価状態 をとる理由はこのように説明される。

一方 $\mathrm{Pd}$ や Pt 錯体では、電荷の不均化を生じて混合原 子価状態をとる。この理由は次のように説明される。架 橋ハロゲン $(\mathrm{X})$ は負電荷を帯びているため、Xが $\mathrm{M} \cdots \mathrm{M}$ 間中央からずれると、 $\mathrm{dz}^{2}$ 軌道のエネルギーは静電相互 作用によりXが近づいた金属イオンでは不安定化し、 遠ざかったイオンでは安定化する。このように格子が歪 むことで $\mathrm{dz}^{2}$ 軌道の縮退が解け、結果的に生じた安定化 した軌道と不安定化した軌道のうち、安定化した軌道に 電子が収容される。これにより、混合原子価状態（=不 均化状態 (Fig. 3(b)) ) が安定化される。このような効果 は、広い意味での Jahn-Teller 効果ともいえるが、原子 ( 格子) の変位と電子のエネルギーが強く相互作用してい るので、固体物性の分野では電子一格子相互作用 $(S)$ と 呼ばれている。より一般的には、 $S$ は $U$ に競合する作用 であることから、負の $U\lrcorner$ の種としても知られている。

ここで、SとUを用いて両状態のエネルギー差につい て、より定量的に議論したい。 X が $\mathrm{M} \cdots \mathrm{M}$ 間中央から ずれることによって変化する $\mathrm{dz}^{2}$ 軌道のエネルギーを $S$ と定義すると、混合原子価状態は平均原子価状態と比較 して 1 電子あたり $S$ だ安定化する一方、電子対の形成 によりUだけ不安定化することがわかる。したがって、 $U<S$ では混合原子価状態、 $S<U$ では平均原子価状態 が基底状態となる。金属イオンによって基底状態が異な る理由は、主に価電子の空間的広がりの違いによって $U$ の大きさが異なることに起因している。この大きさは、 $\mathrm{Ni}(\sim 6 \mathrm{eV})^{13)} 、 \mathrm{Pd}(\sim 1.5 \mathrm{eV})^{14)} 、 \mathrm{Pt}(\sim 1 \mathrm{eV})^{15}$ 程度と見積も られている。

\section{3. 混合原子価錯体としての $M X$ 錯体}

混合原子価錯体は、原子価間電荷移動（IVCT）な ぞ、その電子移動に対する興味から、固体物性の一分野 として古くから盛んに研究が行われてきた。また固体 のみならず、溶液化学においても Creutz-Taube イオン: $\left[\left(\mathrm{NH}_{3}\right)_{5} \mathrm{Ru}^{\mathrm{II}}(\mathrm{pz}) \mathrm{Ru}^{\mathrm{III}}\left(\mathrm{NH}_{3}\right)_{5}\right]^{5+}(\mathrm{pz}=\text { pyrazine })^{16)}$ を代表とする 混合原子価錯体について、光電子移動などの研究が実験、 理論両面で盛んに行われている ${ }^{17)}$ 。混合原子価につい 
ては、1967 年に Robin と Dayによって混合原子価化合 物の体系化がなされ、電荷の不均化の度合いに応じてク ラスIからクラス III まで分類されている ${ }^{18)}$ 。このクラ ス分けは現在でも混合原子価を議論する際よく用いられ る。ここで各クラスの特徴を簡単に紹介したい。

クラス I : 各酸化状態が非常に異なった環境にあり、 二つの異なる酸化状態の間には相互作用はほとんどな い。電気伝導性は絶縁体的 $\left(>10^{10} \Omega \mathrm{cm}\right)$ である。

クラス II : 各酸化状態の環境は異なるものの、クラス I に比べて環境の違いは小さく、可視、或いは近赤外 領域に IVCT 遷移が観測される。電気伝導性は半導体的 (10-10 $\Omega \mathrm{cm})$ である。

クラス III : 各酸化状態の環境が等価になり、それぞ れを区別することはできない。クラス III はさらに電子 の非局在度合いに応じて、電子が局在化したクラス IIIA と非局在化したクラス IIIB に分類される。

MX 錯体を Robin-Day の定義に基づいてクラス分けを すると、 Pd, Pt 錯体はクラス II、Ni 錯体はクラス IIIA に 分類される。本稿では、 $\mathrm{Pd}, \mathrm{Pt}$ 錯体の電子状態を単純化 して $-\mathrm{X} \cdots \mathrm{M}^{2+} \cdots \mathrm{X}-\mathrm{M}^{4+}-\mathrm{X} \cdots$ と表記しているが、より厳 密には $-\mathrm{X} \cdots \mathrm{M}^{3-\delta} \cdots \mathrm{X}-\mathrm{M}^{3+\delta}-\mathrm{X} \cdots(\delta$ : 不均化の度合い、 $0 \leq$ $\delta \leq 1)$ のように非整数の酸化状態をとっており、また、 $\delta$ の大きさに応じてクラス I からクラス III まで連続的 に変化し、クラス間に明確な境界が存在しないことに注 意しなければいけない。

\section{4. $M X$ 錯体の電子励起状態}

MX 錯体については強い電荷移動吸収、大きな Stokes シフトを伴う発光、高次の共鳴 Raman 散乱、ソリトン やポーラロンに基づく物性など、数多くの興味深い物性 がこれまでに研究されてきた。これらを理解するために は電子励起状態について理解する必要があるのでここで 簡単に解説したい。

Fig. 4 に混合原子価状態のハロゲン歪みに対する断熱 ポテンシャルを示す。ポテンシャル曲線は厳密には平衡

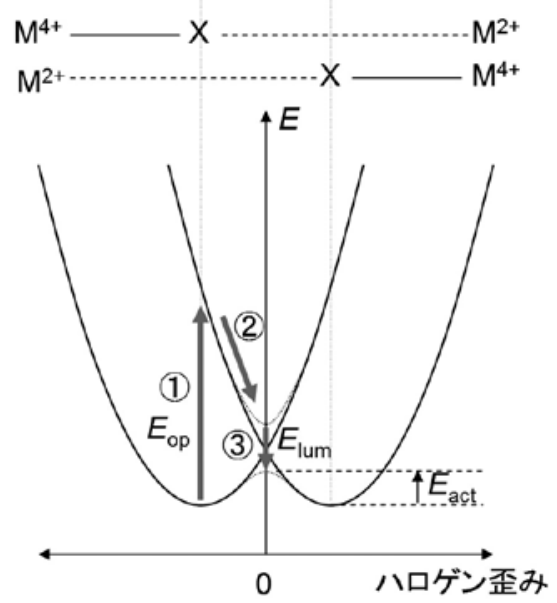

Fig. 4 Adiabatic potential surface in mixed valence state.
位置（極小）に対し非対称であるが、理論的には近似し て調和振動子 (二次曲線) で表すことが多い。この場合、 ポテンシャル曲線は中央からずれた二つの二次曲線で表 され、それぞれ縮退した $\mathrm{M}^{2+} \cdots \mathrm{X}-\mathrm{M}^{4+}$ と $\mathrm{M}^{4+}-\mathrm{X} \cdots \mathrm{M}^{2+}$ の 状態を表している。両状態のポテンシャル曲線が交差す る付近では相互作用によりエネルギーが分裂している。 ここではまず、 $\mathrm{M}^{4+}-\mathrm{X} \cdots \mathrm{M}^{2+}$ という基底状態から話を始 める。光励起により、 $\mathrm{M}^{2+}$ サイトから $\mathrm{M}^{4+}$ サイトに電子 移動が起こる際、Franck-Condon 原理のため、配置座標 上垂直に遷移が起こる。この電子移動により、過渡的に ハロゲンが歪んだ平均原子価状態 $\left(\mathrm{M}^{3+}-\mathrm{X} \cdots \mathrm{M}^{3+}\right)$ が生じ る (過程 (1))。この状態は電荷移動励起子 (CTE: Charge Transfer Exciton) とよばれている。その後、平均原子価 状態では八ロゲンは歪む必然性がないため、金属間中央 に向かって格子緩和を起こした平均原子価状態 $\left(\mathrm{M}^{3+}-\mathrm{X}-\right.$ $\mathrm{M}^{3+}$ )を生じる (過程(2)）。この状態は、自分自身で電子 を局在化してしまう一種の自縄自縛状態なので、自己束 縛励起子 (STE: Self Trap Exciton) とよばれている。その 後、多くはSTEからの発光により基底状態に戻る (過 程(3) )が、無輻射的に失活し、ソリトン対を生じる場合 もある (後述)。発光エネルギー $\left(E_{\text {lum }}\right)$ は格子緩和によっ て安定化した STEから起こるので、 $E_{\mathrm{opt}}$ に比べ非常に小 さくなる。そのため、本化合物系は非常に大きい Stokes シフトを示す。Fig. 5 にそれぞれの状態を模式的に示す。 通常はSTEから逆向きに電子移動して基底状態に戻る が ( 過程(3))、ある割合で隣のサイトから電子移動を起 こす場合 (過程(4) ) や、元の CT と同じ向きに電子移動 を起こす場合 (過程(5) ) があり、それぞれ鎖の途中で混 合原子価の位相が反転したスピンソリトン対と荷電ソリ トン対が長寿命励起状態として生じる。これらのソリト ンはドミノ倒しのように電子移動を繰り返し、一次元鎖 状を拡散することが出来るが、ソリトン同士が衝突する と対消滅し基底状態に戻る。光励起ソリトンの存在は光 誘起吸収 (PA: photoinduced absorption) スペクトルによつ て観測可能であり、 $E_{\mathrm{opt}}$ の約半分のエネルギー領域にミ ッドギャップ吸収として観測される。また、ソリトン対

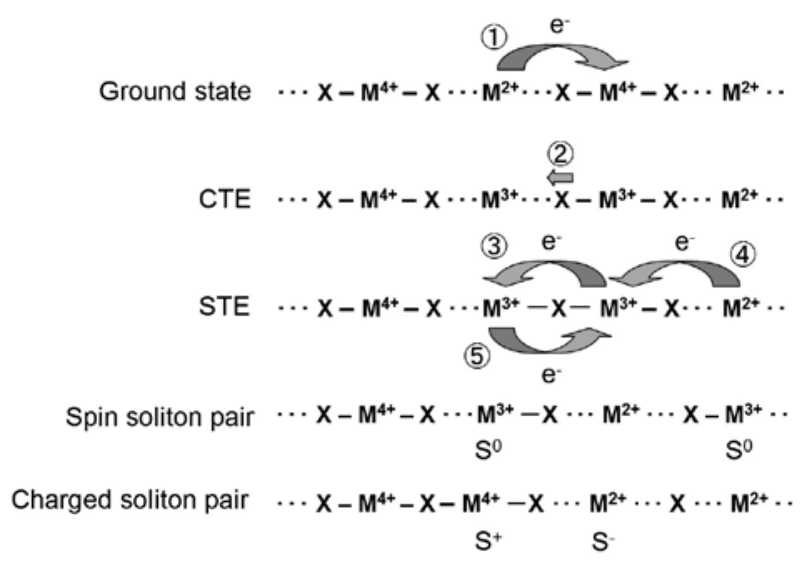

Fig. 5 Schematic drawing of ground and excited states. 
の生成は熱エネルギーによっても可能であるが、その場 合の活性化エネルギー $\left(E_{\mathrm{act}}\right)$ は、相互作用が小さい場合 には $E_{\mathrm{opt}}$ の $1 / 4$ 程度となる。

\section{5. $\mathrm{MX}$ 錯体の構造と電子状態の相関}

MX 錯体については、現在までに中心金属、架橋ハロ ゲン、面内配位子、対イオンを変えることで 300 種類以 上が報告されており、その構造と電子状態の相関につい て岡本、山下らにより精力的に研究されている ${ }^{19)}$ 。ここ ではその内容について簡単に紹介したい。

Fig. 6 に一連の MX 錯体における隣接金属イオン間距 離 $(\mathrm{M} \cdots \mathrm{M}$ 距離) に対する金属一ハロゲン間距離 $(\mathrm{M} \cdots \mathrm{X}$ 距離) のプロットを示す。破線は、Xが金属間中央にあ るときの $\mathrm{M} \cdots \mathrm{X}$ 距離を表している。また、破線よりも 下にある点は $\mathrm{M}^{4+} \cdots \mathrm{X}$ 距離、上にある点は $\mathrm{M}^{2+} \cdots \mathrm{X}$ 距離 を表している。このプロットからいくつかの特徵が読み 取れ、以下のように理解されている。(1) $\mathrm{M}^{4+} \cdots \mathrm{X}$ 距離は $\mathrm{M} \cdots \mathrm{M}$ 距離に殆ど依存しない。これは $\mathrm{M}^{4+}$ と $\mathrm{X}$ の間に は明確な化学結合が存在しており、核間反発によりこれ 以上短くなることができないことを示している。(2)同じ

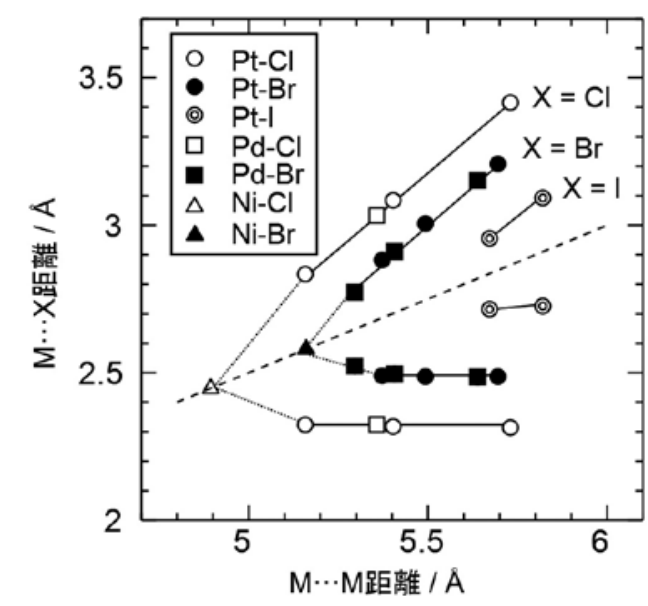

Fig. $6 M \cdots X$ distances of a series of MX chains as a function of $\mathrm{M} \cdots \mathrm{M}$ distances.

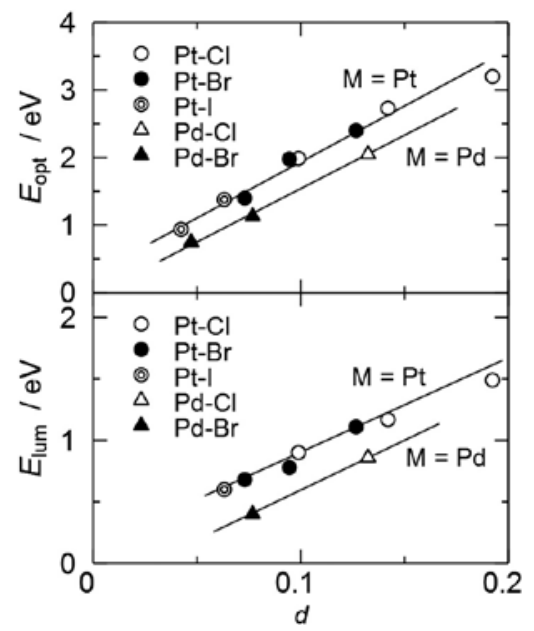

Fig. $7 E_{\text {opt }}$ and $E_{\text {lum }}$ of a series of MX chains as a function of $d$ parameter.
$\mathrm{M} \cdots \mathrm{M}$ 距離であっても $\mathrm{X}=\mathrm{I}<\mathrm{Br}<\mathrm{Cl}$ の順に $\mathrm{X}$ の金属間 中央からのずれが大きくなる。これはハロゲン化物イ オンのイオン半径の違い $\left(\mathrm{Cl}^{-}: 1.67 \AA\right.$, $\mathrm{Br}: 1.82 \AA$, I: 2.06 Å)に起因していると考えられている ${ }^{20)}$ 。(3) Xのずれは、 金属イオンの種類に依らない。これは金属イオンのイオ ン半径に殆ど違いがない $\left(\mathrm{Pd}^{4+}: 0.76 \AA \mathrm{Pt}^{4+}: 0.77 \AA\right)$ ため であると考えられている ${ }^{20)}$ 。(4) X の種類ごとにみると、 いずれの場合も $\mathrm{M} \cdots \mathrm{M}$ 距離が短くなるにつれて架橋八 ロゲンが金属間中央に近づく。これは、Fig. 4 における 二つの二次曲線が近づくことに対応している。

岡本らは、Xのずれを定量的に評価するため、次式で 表される $d($ distortion) パラメータを導入した。

$$
d=\frac{l\left(\mathrm{M}^{2+} \cdots \mathrm{X}\right)-l\left(\mathrm{M}^{4+} \cdots \mathrm{X}\right)}{l(\mathrm{M} \cdots \mathrm{M})}
$$

ここで、l( $\left.\mathrm{M}^{2+} \cdots \mathrm{X}\right) 、 l\left(\mathrm{M}^{4+} \cdots \mathrm{X}\right) 、 l(\mathrm{M} \cdots \mathrm{M})$ はそれぞれ $\mathrm{M}^{2+} \cdots \mathrm{X}$ 距離、 $\mathrm{M}^{4+} \cdots \mathrm{X}$ 距離、 $\mathrm{M} \cdots \mathrm{M}$ 距離を表している。

Fig. 7 に $E_{\mathrm{opt}}$ および $E_{\mathrm{lum}}$ の $d$ パラメー夕依存性を示す。 このプロットでは、Xの種類に依らず $d$ と $E_{\mathrm{opt}} 、 E_{\mathrm{lum}}$ は 金属イオン種ごとによい相関を示している。Xの種類に 依らない理由は、 $d$ パラメータではイオン半径の違いが 相殺されているためであると考えられる。それぞれの金 属イオンについてみると、 $d$ の減小とともに、 $E_{\mathrm{opt}} E_{\mathrm{lum}}$ ともに減小しており、これは Fig. 4 における二つの二次 曲線が近づいたためであると理解される。

\section{3. 擬一次元混合原子価一平均原子価相境界の探索 ${ }^{211}$}

\section{1. 研究の着想・戦略}

これまでに述べた事柄を踏まえると、熱エネルギーによる 電荷の動的挙動を創出する (= $E_{\text {act }}$ を小さくする )ためには、 $\mathrm{M} \cdots \mathrm{M}$ 距離を短くすることが重要であることがわかる。そこ で我々は、混合原子価錯体の $\mathrm{M} \cdots \mathrm{M}$ 距離を短くすることで 平均原子価状態に近づけ、両相の境界を探索することにし た。 $\mathrm{M} \cdots \mathrm{M}$ 距離を縮める手段としては、結晶への圧力印加 が有効である。固体物性の分野では、ダイヤモンドアンビル セルやクランプセルにサンプルを入れて、実際に物理的圧力 を加える方法が確立されているが、この方法ではサンプルを 密閉する必要があるため、測定手法が限られる。そこで我々 は、分子間力を用いる化学的圧力に着目した。化学的圧力 といえば、軽水素を重水素に置換する方法や、長鎖アルキ ル基を導入する方法 (ファスナー効果 ) などが知られており、 後者を選択した。

我々の研究に先立ち、九州大学の君塚らによっ て、有機溶媒中で一次元鎖構造を維持し、サーモ クロミズムを示す $\mathrm{Pt}$ 錯体 $\left[\mathrm{Pt}(\mathrm{en})_{2} \mathrm{Br}\right]\left(\mathrm{C}_{16}-\mathrm{Y}\right)_{2}\left(\mathrm{C}_{16}-\mathrm{Y}=\right.$ dihexadecanesulfosuccinate) が報告されていた ${ }^{22)}$ 。我々は、 この錯体の室温での $E_{\mathrm{opt}}(=1.36 \mathrm{eV})$ が、既報の $\mathrm{Pt}-\mathrm{Br}$ 錯体 


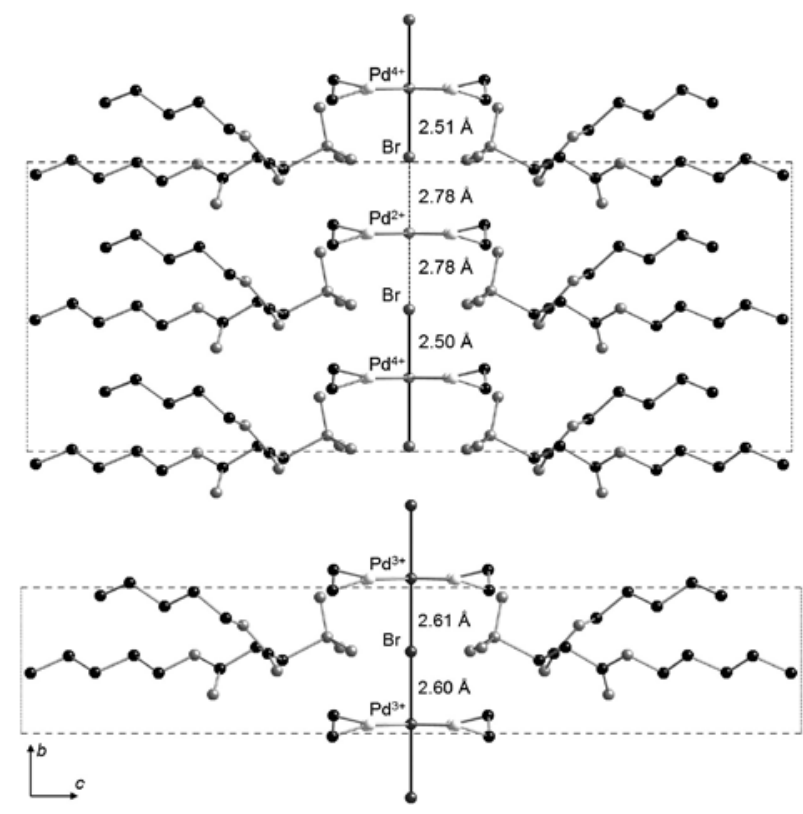

Fig. 8 Crystal structure of $\left[\mathrm{Pd}(\mathrm{en})_{2} \mathrm{Br}\right]\left(\mathrm{C}_{5}-\mathrm{Y}\right)_{2} \cdot \mathrm{H}_{2} \mathrm{O}$ at $250 \mathrm{~K}$ (upper) and $150 \mathrm{~K}$ (lower). Dashed square shows unit cell of the crystal.

中で最小の $E_{\mathrm{opt}}$ を示す $\left[\mathrm{Pt}(\mathrm{chxn})_{2} \mathrm{Br} \mathrm{Br}_{2}(1.40 \mathrm{eV})^{23)}\right.$ のそれよ りも小さいことに着目し、本錯体ではファスナー効果が働い ているに違いないと考えた。そこで早速、 $\mathrm{Pd}-\mathrm{Br}$ 錯体の合成 に取りかかつた。Pd-Br 錯体を用いた理由は、研究開始時 点で $\left[\mathrm{Pd}(\mathrm{chxn})_{2} \mathrm{Br}\right] \mathrm{Br}_{2}$ が既存の錯体中で最も小さい $E_{\mathrm{opt}}(=$ $0.75 \mathrm{eV})^{23)}$ を持ち、最も平均原子価状態に近いと考えたた めである。

\section{2. $\left[\mathrm{Pd}(\mathrm{en})_{2} \mathrm{Br}\right]\left(\mathrm{C}_{5}-\mathrm{Y}\right)_{2} \cdot \mathrm{H}_{2} \mathrm{O}$ の構造と電子状態}

我々はまず始めに、炭素鎖数 (n) が 5 から 16 までの 一連の錯体 : $\left[\mathrm{Pd}(\mathrm{en})_{2} \mathrm{Br}\right]\left(\mathrm{C}_{\mathrm{n}}-\mathrm{Y}\right)_{2} \cdot \mathrm{H}_{2} \mathrm{O}$ の合成を行い、これ らのうち最も結晶性のよい $\mathrm{n}=5$ の錯体の構造と電子状 態を詳しく調べた。 $250 \mathrm{~K}$ で単結晶 $\mathrm{X}$ 線構造解析を行っ たところ、架橋 $\mathrm{Br}$ イオンは $\mathrm{Pd}$ 原子間の中央からずれ ていたため、従来どおりの混合原子価状態であることが 分かった (Fig. 8( 上))。一方、 $150 \mathrm{~K}$ で構造解析したと ころ、架橋 $\mathrm{Br}$ イオンは $\mathrm{Pd}$ 原子間のほぼ中央に観測さ

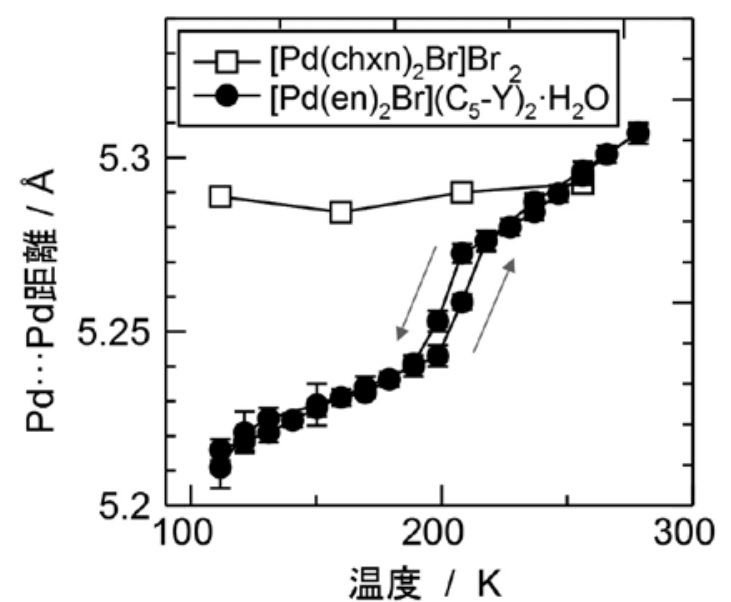

Fig. 9 Temperature dependence of $\mathrm{Pd} \cdots \mathrm{Pd}$ distance in $\left[\mathrm{Pd}(\mathrm{en})_{2} \mathrm{Br}\right]$ $\left(\mathrm{C}_{5}-\mathrm{Y}\right)_{2} \cdot \mathrm{H}_{2} \mathrm{O}$.
れ、平均原子価状態が示唆された (Fig. 8(下))。詳細を 調べるために Pd ․PPd 距離の温度変化を測定したところ、 典型的な混合原子価錯体である $\left[\mathrm{Pd}(\mathrm{chxn})_{2} \mathrm{Br} \mathrm{Br}_{2}\right.$ では殆 ど変化しない $(5.29 \AA)$ のに対して、この化合物は $5.31 \AA$ $(290 \mathrm{~K})$ から $5.21 \AA(110 \mathrm{~K})$ まで $0.1 \AA(2 \%)$ 程度の大きい 熱収縮を示した (Fig. 9)。これは、高温で活発であった アルキル鎖の熱運動が低温で凍結したために Pd 原子間 距離が短くなったと理解できる。すなわち、本系はア ルキル鎖間の引力的相互作用による $\mathrm{Pd} \cdots \mathrm{Pd}$ 距離を縮め る効果と、アルキル鎖の熱摇らぎによる $\mathrm{Pd} \cdots \mathrm{Pd}$ 距離を 広げる効果が競合しているといえる。さらに、約 $205 \mathrm{~K}$ $(5.27 \AA)$ でヒステリシスを伴う Pd $\cdots P d$ 距離の不連続 (一 次相転移) が観測された。

次に、電子状態の変化と相転移の関係を調べるために、 ラマンスペクトルの測定を行った。ラマンスペクトルは 電子状態を決定する有効な手段である。混合原子価状 態では $\mathrm{Br}-\mathrm{Pd}^{4+}-\mathrm{Br}$ の対称伸縮モードに基づく共鳴ラマン 散乱が観測されるのに対して、平均原子価状態では架橋 ハロゲンが金属間の中央にあるために禁制となる。Fig. 10 に示すように、 $205 \mathrm{~K}$ 以上では $120 \mathrm{~cm}^{-1}$ 付近に $\mathrm{Pd}^{4+}$ $\mathrm{Br}$ の伸縮振動に基づくピークが観測されるのに対して、 $200 \mathrm{~K}$ 以下では観測されなくなり、相転移に伴い平均原 子価状態が実現されていることが確認された。ESR ス ペクトル、熱容量測定などからもこれを支持する結果が 得られ、この相転移により混合原子価状態から平均原子 価状態に変化していることが明らかとなった。

$\mathrm{Pd} \cdots \mathrm{Pd}$ 距離が大きく変化していることから、 $E_{\mathrm{opt}}$ の 変化が期待される。そこで、偏光反射スペクトルを

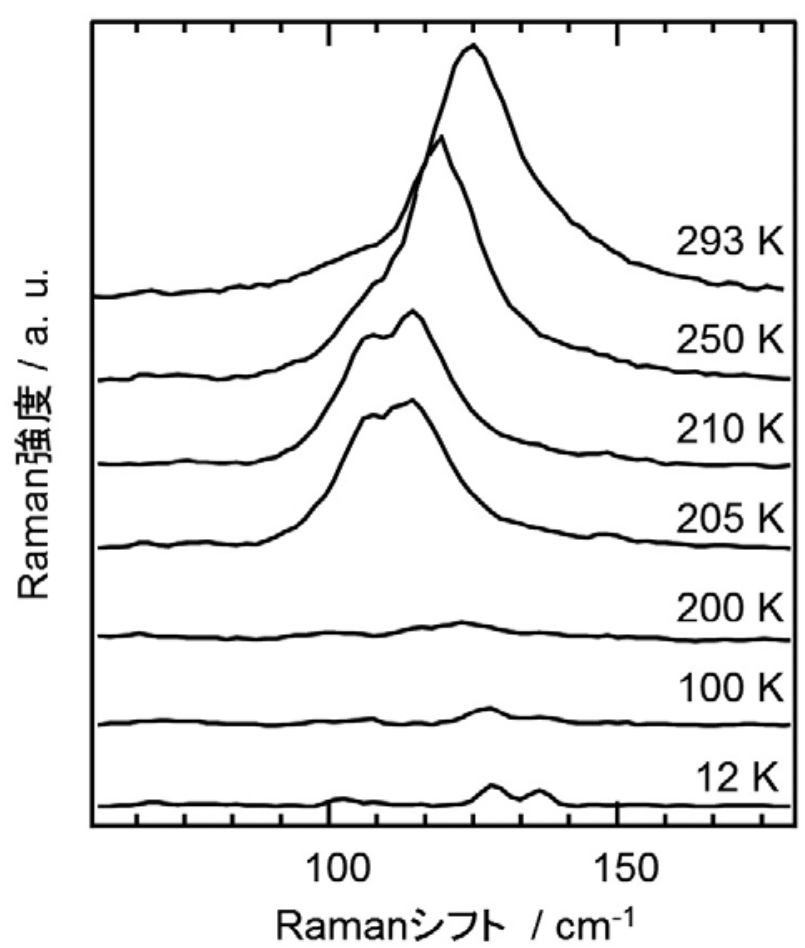

Fig. 10 Temperature dependence of Raman spectra in $\left[\mathrm{Pd}(\mathrm{en})_{2} \mathrm{Br}\right]$ $\left(\mathrm{C}_{5}-\mathrm{Y}\right)_{2} \cdot \mathrm{H}_{2} \mathrm{O}$. 


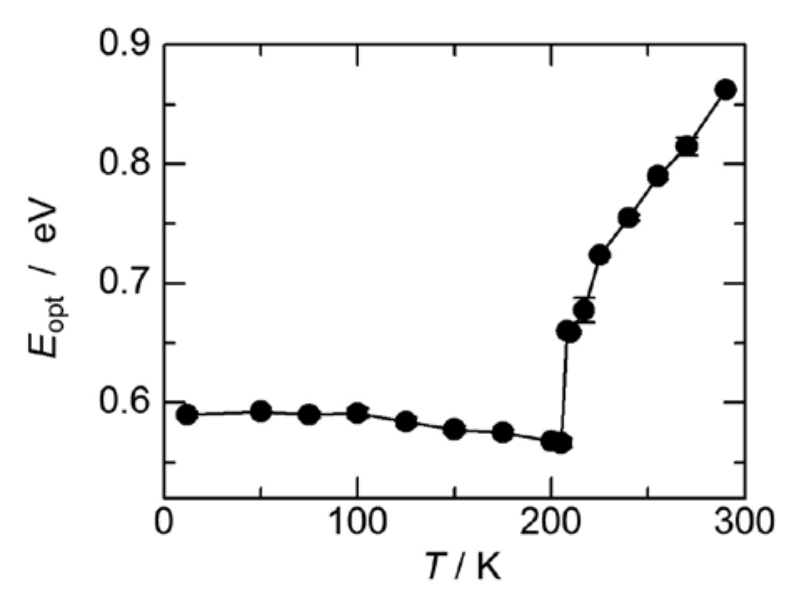

Fig. 11 Temperature dependence of $E_{\mathrm{opt}}$ in $\left[\mathrm{Pd}(\mathrm{en})_{2} \mathrm{Br}\right]\left(\mathrm{C}_{5}-\mathrm{Y}\right)_{2} \cdot \mathrm{H}_{2} \mathrm{O}$.

Kramers-Kronig 変換して得られる光学伝導度スペクトル から $E_{\mathrm{opt}}$ を見積もつた。 $E_{\mathrm{opt}}$ を温度の関数でプロットす ると Fig. 11 のよになる。室温から約 $205 \mathrm{~K}$ までは温 度が下がるにつれてピーク位置が低エネルギーへとシフ トしている。これは、温度低下とともに Pd $\cdots P d$ 距離が 縮んだことによる。一方、205K 以下では $\mathrm{Pd} \cdots \mathrm{Pd}$ 距離が 縮んでいるにもかかわらず $E_{\mathrm{opt}}$ はほとんど変わらない。 この違いは、両電子状態における電子遷移の起源を考 えると説明できる。混合原子価状態 $(205 \mathrm{~K}$ 以上) では、 電子遷移は $\mathrm{Pd}^{2+}$ から $\mathrm{Pd}^{4+}$ へ IVCT 遷移であるのに対 し、平均原子価状態 (205 K 以下) では、 $\mathrm{Pd}^{3+}-\mathrm{Pd}^{3+}$ から 不均化状態である $\mathrm{Pd}^{2+}-\mathrm{Pd}^{4+}$ 状態 $\left(\right.$ より厳密には $\mathrm{Pd}^{2+}-$ $\mathrm{Pd}^{4+}$ 状態 $(|\mathrm{L}\rangle)$ と $\mathrm{Pd}^{4+}-\mathrm{Pd}^{2+}$ 状態 $(|\mathrm{R}\rangle)$ の線形結合である $|\mathrm{L}\rangle-|\mathrm{R}\rangle$ 状態 ) を生じる。この遷移は、バンド描像では $U$ により分裂した $\mathrm{dz}^{2}$ 軌道の下部 Hubbard バンドから上部 Hubbard バンドへの遷移と説明される。ここで、両電子 状態における遷移エネルギーを見積もると次のようにな る。混合原子価状態では、Fig. 3 に示したように $\mathrm{M}^{2+} サ$ イトと $\mathrm{M}^{4+}$ サイトで $\mathrm{dz}^{2}$ 軌道のエネルギーに $2 S$ の差が あるので、IVCT 遷移による CTE の生成には $2 S$ のエネ

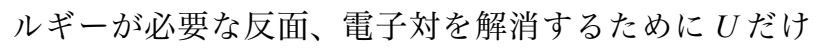
安定化する。そのため、 $E_{\mathrm{opt}}$ は $2 S-U$ と見積もられる ${ }^{24)}$ 。

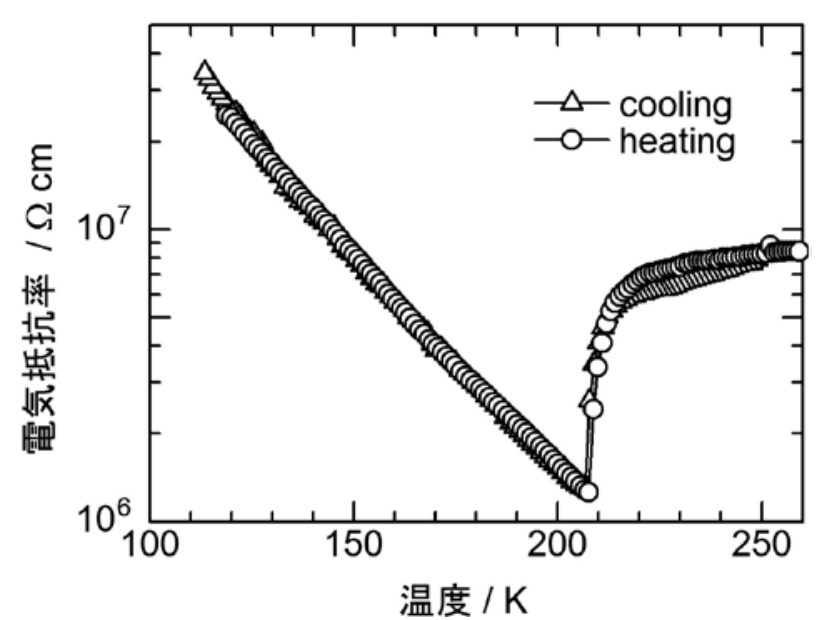

Fig. 12 Temperature dependence of electrical resistivity in $\left[\mathrm{Pd}(\mathrm{en})_{2} \mathrm{Br}\right]\left(\mathrm{C}_{5}-\mathrm{Y}\right)_{2} \cdot \mathrm{H}_{2} \mathrm{O}$.
一方、平均原子価状態では Xが金属間中央にある混合 原子価状態 $\left(\mathrm{M}^{2+}-\mathrm{X}-\mathrm{M}^{4+}\right)$ への遷移であるため、 $E_{\mathrm{opt}}$ は $U$ で表される ${ }^{24)}$ 。Uは、一般に金属イオンのみに依存し、 周りの環境にほとんど依存しないので $205 \mathrm{~K}$ 以下ではピ ークは温度変化しなかったと理解できる。したがって、 この相転移の起源は、温度低下に伴う $S$ の減小によると いえる。このように、化学的圧力を利用し $S$ を抑制する ( 格子が歪む利得を無くす)ことで、Pd 錯体で平均原子 価状態を実現することができた。

Fig. 12 に $\left[\mathrm{Pd}(\mathrm{en})_{2} \mathrm{Br}\right]\left(\mathrm{C}_{5}-\mathrm{Y}\right)_{2} \cdot \mathrm{H}_{2} \mathrm{O}$ の電気抵抗率の温度 変化を示す。半導体の電気抵抗は、温度低下とともに増 大するのが普通であるが、本錯体では混合原子価領域に おいて、電気抵抗率が温度低下とともに減小する通常と 逆の挙動を示した。これは、温度低下とともに $\mathrm{Pd} \cdots \mathrm{Pd}$ 距離が短くなり、それによって $E_{\text {act }}$ が小さくなったため であると解釈できる。さらに、 $215 \mathrm{~K}$ 以下で急激に電気 抵抗率の減小が観測された。これは、この温度領域では 混合原子価状態と平均原子価状態のエネルギーが拮抗し ており、そのために電荷の動的な摇らぎが起きている考 えられる。

以上のように我々は、従来混合原子価状態をとること が知られていた $\mathrm{Br}$ 架橋 $\mathrm{Pd}$ 錯体に対し、化学的圧力を 導入することにより、初めて平均原子価状態を実現し、 また、両電子状態の境界領域において、動的な価数摇動 を創出することに成功した。今後は、固体 NMR などを 用いて価数摇動についてより詳細を明らかにしていきた w。

\section{STM を利用した Ni-Pd 混合金属錯体におけ る局所原子価構造の直接観測 25)}

\section{1. 研究の着想 ・目的}

$\mathrm{MX}$ 錯体の電子基底状態は金属イオンに依存し、我々 の開発した $\left[\mathrm{Pd}(\mathrm{en})_{2} \mathrm{Br}\right]\left(\mathrm{C}_{\mathrm{n}}-\mathrm{Y}\right)_{2} \cdot \mathrm{H}_{2} \mathrm{O}$ 以外ではすべての $\mathrm{Pd}$ 、 $\mathrm{Pt}$ 錯体では混合原子価状態、 $\mathrm{Ni}$ 錯体では平均原子価状

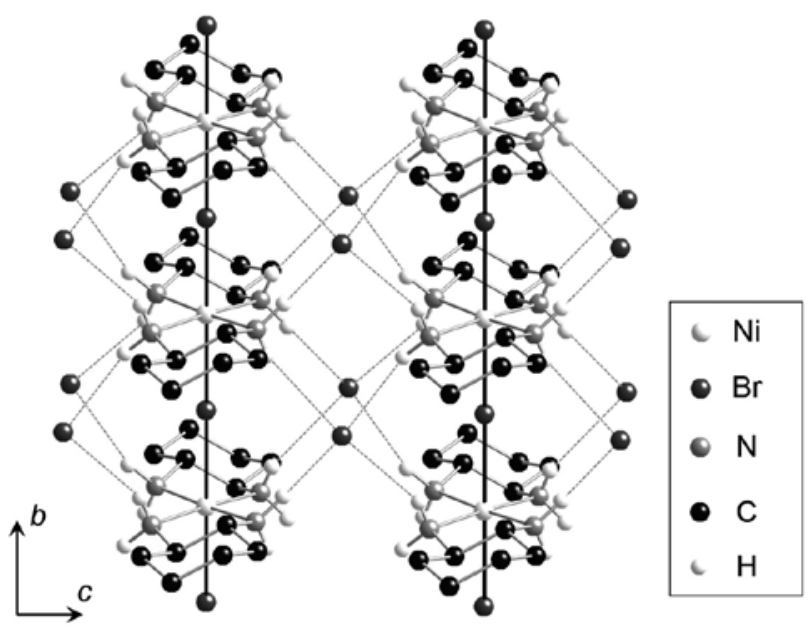

Fig. 13 Crystal structure of $\left[\mathrm{Ni}(\mathrm{chxn})_{2} \mathrm{Br} \mathrm{Br}_{2}\right.$.

Bull. Jpn. Soc. Coord. Chem. Vol. 57 (2011) 
態をとることは既に述べたとおりである。これらの電子 基底状態は $X$ 線構造解析や Raman スペクトルから構造 に関する情報を得て、間接的に見積もられてきており、 電荷を直接観測する手法は皆無であった。そこで我々は、 電荷の情報を直接観測することが可能である走査トンネ ル顕微鏡 $(\mathrm{STM})$ に着目した。この手法は、単に電荷の 情報を直接的に得ることができるだけでなく、同手法の 高い空間分解能を利用して局所的な電荷配列を測定する ことが可能であるため、本研究における目的である電荷 の動的挙動を可視化する手法として有用であると考えら れる。

\section{2. $\left[\mathrm{Ni}(\mathrm{ch} \times n)_{2} \mathrm{Br}_{\mathrm{Br}} \mathrm{Br}_{2}\right.$}

本研究では最初に平均原子価状態をとる $\left[\mathrm{Ni}(\mathrm{chxn})_{2} \mathrm{Br}\right]$ $\mathrm{Br}_{2}$ を測定対象として選んだ。この錯体の結晶構造を Fig. 13 に示す ${ }^{12)}$ 。この錯体は、 $b$ 軸方向に $-\mathrm{Br}^{-} \mathrm{Ni}^{3+}-\mathrm{Br}-$ $\mathrm{Ni}^{3+}-\mathrm{Br}-$ の一次元鎖が伸びており、面内では chxn 配位 子 2 分子が Ni に配位結合している。chxn 配位子の窒素 原子に結合している水素原子と、カウンターイオンの $\mathrm{Br}$ との間に水素結合が存在し、 $b c$ 面内に比較的強い 2 次元的な水素結合ネットワークが存在している。一方、 $a$ 軸方向には chxn 配位子同士の弱い van der Waals 接触 のみが存在しているため、カッターを用いて容易に結晶 の $b c$ 面を䢃開することができる。このようにして䢃開 した結晶をカーボンペーストでステージ上に貼り付け、 STM 測定を行なつた。Fig. 14 に $\left[\mathrm{Ni}(\mathrm{chxn})_{2} \mathrm{Br}\right] \mathrm{Br}_{2}$ の STM 像を示す。約 $5 \times 7 \AA$ おきに輝点が観測された。これは、 $\left[\mathrm{Ni}(\mathrm{chxn})_{2} \mathrm{Br}\right] \mathrm{Br}_{2}$ の一次元鎖 (b 軸 ) 方向の $\mathrm{Ni}-\mathrm{Ni}$ 間距離 $(5.16 \AA)$ 、および垂直 (c 軸 ) 方向の Ni-Ni 間距離, (7.12 Å)に相当することから、Ni イオンの周期性を反映して いることがわかる。

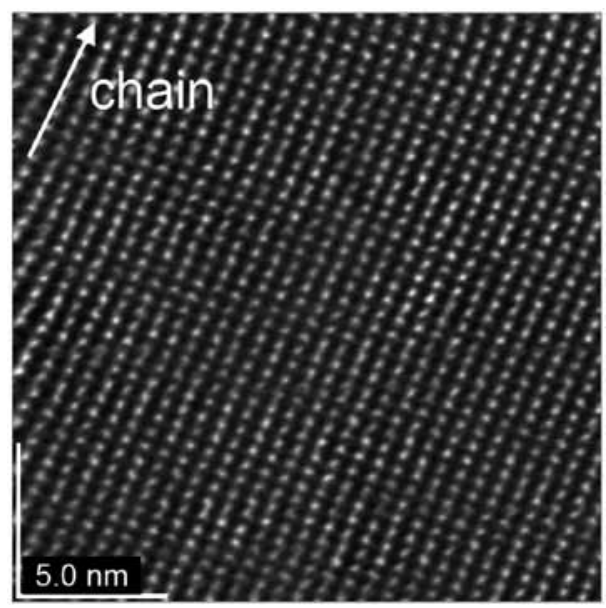

Fig. $14 \mathrm{STM}$ image of $\left[\mathrm{Ni}(\mathrm{ch} \times n){ }_{2} \mathrm{Br} \mathrm{Br}_{2}\right.$.

\section{3. $\left[\mathrm{Pd}(\mathrm{ch} \times n)_{2} \mathrm{Br}_{\mathrm{Br}}\right.$}

次に混合原子価錯体について測定を試みた。測定 対象として、結晶構造が $\left[\mathrm{Ni}(\mathrm{chxn})_{2} \mathrm{Br} \mathrm{Br}_{2}\right.$ と同形の $\left[\mathrm{Pd}(\mathrm{chxn})_{2} \mathrm{Br} \mathrm{Br}_{2}\right.$ を用いた ${ }^{26)}$ 。この錯体は $\left[\mathrm{Ni}(\mathrm{chxn})_{2} \mathrm{Br}\right]$
$\mathrm{Br}_{2}$ と同様に $b c$ 面内に水素結合のネットワークが存在し ているため、容易に $b c$ 面の清浄表面を出すことができ ると思われるためである。

$\left[\mathrm{Pd}(\mathrm{chxn})_{2} \mathrm{Br} \mathrm{Br}_{2}\right.$ の STM 像を Fig. 15 に示す。約 $10 \times 7$ $\AA お$ おき輝点が観測された。この錯体の Pd-Pd 間距離は 一次元方向が $5.29 \AA$ 、垂直方向が $7.07 \AA$ であることから、 輝点は明らかに一次元鎖方向の 2 倍周期構造、すなわち、 $\cdots \mathrm{Pd}^{2+} \cdots \mathrm{Br}^{-} \mathrm{Pd}^{4+}-\mathrm{Br}^{\cdots} \cdot \mathrm{Pd}^{2+} \cdots$ の混合原子価状態を反映し ていることがわかる。また、混合原子価の位相が鎖間 $(c$ 軸方向) でそろっていることがわかる。この結果は、若 林らによるX 線散漫散乱の結果と一致している ${ }^{27)}$ 。

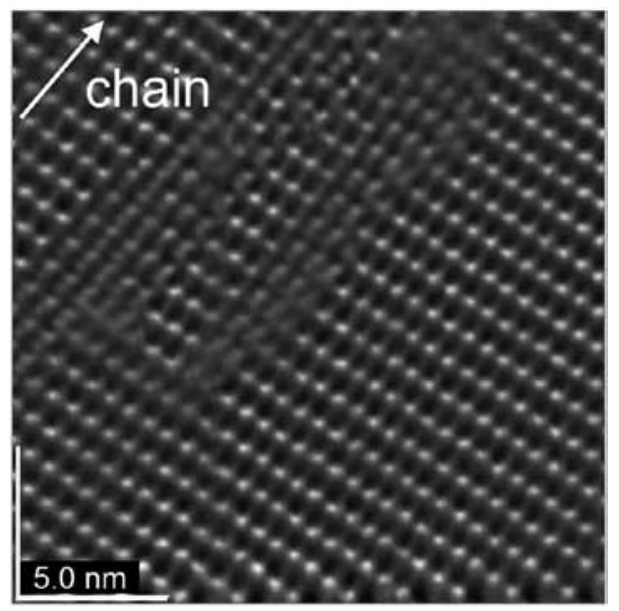

Fig. 15 STM image of $\left[\mathrm{Pd}(\mathrm{ch} \times n){ }_{2} \mathrm{Br}_{\mathrm{Br}}\right.$.

\section{4. トンネル電流の起源}

Fig. 16 に $\left[\mathrm{Ni}(\mathrm{chxn})_{2} \mathrm{Br}_{\mathrm{B}} \mathrm{Br}_{2}\right.$ および $\left[\mathrm{Pd}(\mathrm{chxn})_{2} \mathrm{Br} \mathrm{Br}_{2}\right.$ のバ ンド構造を示す。本 STM 測定は正のサンプルバイアス で測定したので、探針 (Pt/Ir)のフェルミエネルギーから サンプルの伝導帯へのトンネル電流が観測されている ことになる。すなわち $\left[\mathrm{Ni}(\mathrm{chxn})_{2} \mathrm{Br}_{3} \mathrm{Br}_{2}\right.$ では $\mathrm{Ni} の \mathrm{dz}^{2}$ 軌 道からなる上部 Hubbard バンド、 $\left[\mathrm{Pd}(\mathrm{chxn})_{2} \mathrm{Br}\right] \mathrm{Br}_{2}$ では、 $\mathrm{Pd}^{4+}$ の $\mathrm{dz}^{2}$ バンドへのトンネル電流が観測されている ことになる。したがって輝点は、 $\left[\mathrm{Ni}(\mathrm{chxn})_{2} \mathrm{Br}\right] \mathrm{Br}_{2}$ では $\mathrm{Ni}^{3+}(\mathrm{chxn})_{2}$ ユニット、 $\left[\mathrm{Pd}(\mathrm{chxn})_{2} \mathrm{Br}\right] \mathrm{Br}_{2}$ では $\mathrm{Pd}^{4+}(\mathrm{chxn})_{2}$ ユ ニットを表していると考えられる。

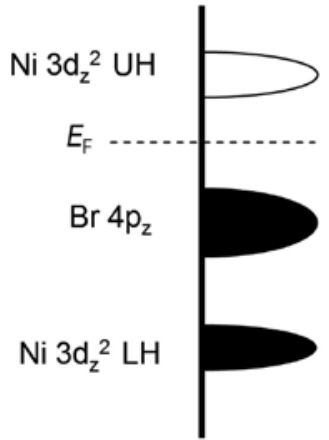

(a)

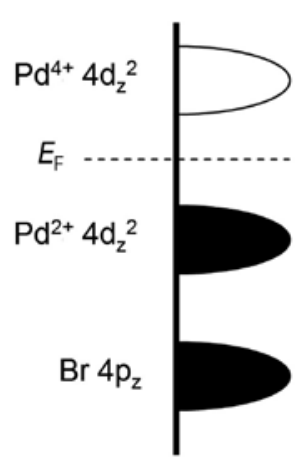

(b)
Fig. 16 Band structure of $\left[\mathrm{Ni}(\mathrm{ch} \times n)_{2} \mathrm{Br}\right] \mathrm{Br}_{2}(\mathrm{a})$ and $\left[\mathrm{Pd}(\mathrm{ch} \times n)_{2} \mathrm{Br}_{3} \mathrm{Br}_{2}\right.$ (b). 
4.5. $\left[\mathrm{Ni}_{1-x} \mathrm{Pd}_{x}(\mathrm{ch} \times n)_{2} \mathrm{Br}\right] \mathrm{Br}{ }_{2}$

最近、Ni と Pd が任意の割合で混合された固溶体 $\left[\mathrm{Ni}_{1}\right.$. ${ }_{x} \mathrm{Pd}_{x}(\mathrm{chxn})_{2} \mathrm{Br}_{\mathrm{BBr}}$ が山下らのグループによって合成され た ${ }^{28)}$ 。こ水らの錯体の電子状態は平均原子価状態と混合 原子価状態とが単結晶中で競合することが期待されるた め興味深い。これまでにも、IRスペクトル29)、光学伝 導度スペクトル ${ }^{29)} 、 \mathrm{ESR}$ スペクトル ${ }^{30} 、 \mathrm{X}$ 線散漫散乱 27) など多くの研究が行われてきており、約 $x=0.8 \sim 0.9$ 付近で平均原子価状態から混合原子価状態へのクロスオ ーバーが起こることが明らかになっている。しかしなが ら、それらはすべてバルクでの測定であるため、その局 所構造についての情報は得られていない。われわれは STM 測定により 2 状態間の競合を分子スケールで観測 することを試みた。
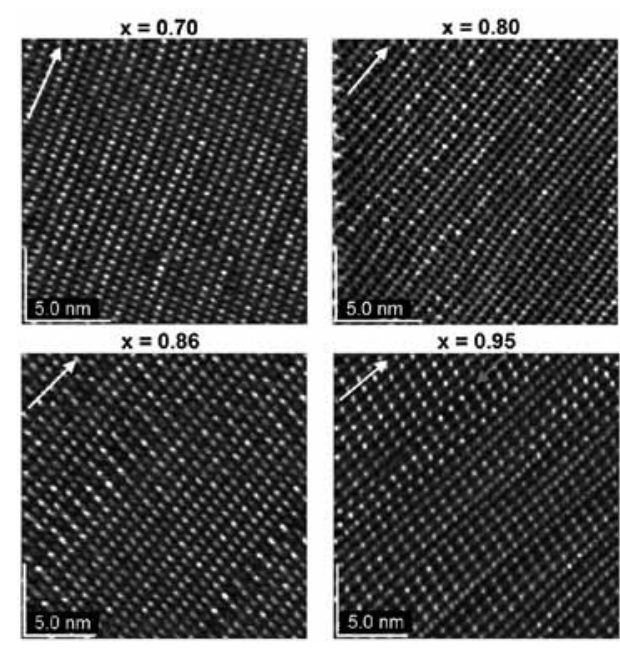

Fig. 17 STM image of $\left[\mathrm{Ni}_{1-x} \mathrm{Pd}_{x}(\mathrm{ch} \times n)_{2} \mathrm{Br}_{\mathrm{Br}}\right.$.

Fig. 17 に 4 種類の試料 $(x=0.70,0.80,0.86,0.95)$ の STM 像を示す。 $x=0.70$ の試料では、ほとんど 2 倍周期構造 は観測されず $\left[\mathrm{Ni}(\mathrm{chxn})_{2} \mathrm{Br}_{3} \mathrm{Br}_{2}\right.$ と同様な像が得られた。 これは、 $x=0.70$ では $\mathrm{Pd}$ の原子価の大部分が $3+$ になり 平均原子化状態をとっていることを示唆している。さら に Pd の割合を増加させると、 $x=0.80$ では、混合原子 価状態に起因する 2 倍周期構造が、所々で観測された。 この像から混合原子価構造の相関長を見積もると、 $\mathrm{b}$ 軸 方向で $8 \pm 4$ サイト、c 軸方向で 1-2 サイトと見積もら れた。 $x=0.95$ では、大部分が 2 倍周期構造をとっており、 $b$ 軸方向の相関長は測定領域 ( $20 \mathrm{~nm} \approx 40$ サイト) 以上で あり、 $c$ 軸方向の相関は $8 \pm 4$ サイトであることがわか つた。混合原子価構造の相関長については、若林らによ って、X 線散漫散乱から見積もられているが 27)、STM とX線散漫散乱からそれぞれ見積もられた相関長はよ い一致を示すことがわかった。

\section{5. ソリトンの観測}

さらに $x=0.95$ の試料の STM 像において非常に興味 深い現象が観測された。Fig. 17 中の灰色の矢印で示し
た一次元鎖は、混合原子価の位相が鎖内で反転している ことがわかる。これは、Fig. 5 に示したソリトンの模式 図と一致する。原子価交替の位相が反転するサイト (ソ リトン幅) はハロゲン架橋 Pd 錯体では、10 金属サイト 程度に広がりをもっていることが理論的に予想されてい たが、今回 STM によって、はじめてソリトンの広がり を実空間において観測することができた。今回観測され たソリトンのダイナミクスについては今のところ不明で あるが、Ni と Pd のエネルギーレベルが異なるため、今 回観測されたソリトン構造は Ni サイトによってピン止 めされたものである可能性が高いと考えられる。

\section{6. 終わりに}

我々は本研究において、Pd 錯体で混合原子価一平均 原子価相転移を実現するとともに、両相の境界領域で 電荷の動的挙動を創出することに成功した。また、 $\left[\mathrm{Ni}_{1}\right.$. ${ }_{x} \mathrm{Pd}_{x}(\mathrm{chxn})_{2} \mathrm{Br}_{3} \mathrm{Br}_{2}$ において局所的な電荷配列を分子レべ ルで可視化することに成功した。しかしながら、本研究 の最終目的である電荷の動的挙動自体を分子レベルで可 視化することには未だ成功していない。そのためには、 混合原子価一平均原子価相転移を示し、且つSTM の測 定が可能な新規錯体の開発が不可欠であり、これは今後 の課題である。

本研究は文部科学省科学研究費補助金「若手研究 (B)」 の支援を受けて行われた。また本研究は、東北大学の山 下正廣教授および学生諸子、東京大学の岡本博教授グル ープ、SPring8 の高田昌樹教授グループ、名古屋大の黒 田新一教授グループ、大阪大の中澤康浩教授グループ、 九州大の君塚信夫教授グループなど、多くの方々の多大 な支援のもとで行わ机た。この場を借りて御礼申し上げ たい。

\section{文献}

1) (a) E. Collet, M. H. Lemee-Cailleau, M. Buron-Le Cointe, H. Cailleau, M. Wulff, T. Luty, S. Koshihara, M. Meyer, L. Toupet, P. Rabiller, S. Techert, Science, 300, 612 (2003). (b) C. W. Siders, A. Cavalleri, Science, 300, 591 (2003).

2) (a) N. Shimamoto, S. Ohkoshi, O. Sato, K. Hashimoto, Inorg. Chem., 41, 678 (2002). (b) H. Tokoro, S. Ohkoshi, T. Matsuda, K. Hashimoto, Inorg. Chem., 43, 5231 (2004). (c) H. Tokoro, K. Hashimoto, S. Ohkoshi, J. Magn. Magn. Mater., 310, 1422 (2007).

3) D. Kiriya, H.-C. Chang, S. Kitagawa, J. Am. Chem. Soc., 130, 5515 (2008).

4) H. Wolffram, Dissertation, Königberg (1990).

5) B. M. Craven, D. Hall, Acta Crsyt., 14, 475 (1961).

6) (b) S. Yamada, R. Tsuchida, Bull. Chem. Soc. Jpn., 29, 421 (1956). (c) S. Yamada, R. Tsuchida, Bull. Chem. Soc. Jpn., 29, 894 (1956).

7) S. Kida, Bull. Chem. Soc. Jpn. 38, 1804 (1965).

8) (a) R. J. H. Clark, M. L. Franks, W. R. Trumble, Chem. Phys. Lett., 
41, 287 (1976). (b) R. J. H. Clark, M. Kurmoo, D. N. Mountney, H. Toftlund, J. Chem. Soc., Dalton Trans., 1982, 1851 (1982). (c) R. J. H. Clark, Chem. Soc. Rev., 19, 107 (1990). (d) R. J. H. Clark, Adv. Infrared Raman Spectr., 11, 95 (1983).

9) (a) H. Okamoto, Y. Kaga, Y. Shimizu, Y. Oka, Y. Iwasa, T. Mitani, M. Yamashita, Phys. Rev. Lett., 80, 861 (1998). (b) Tanino, H.; Kobayashi, K. J. Phys. Soc. Jpn., 52, 1446 (1983).

10) (a) H. Tanino, K. Kobayashi, J. Phys. Soc. Jpn., 52, 1446 (1983). (b) S. Tomimoto, H. Nansei, S. Saito, T. Suemoto, J. Takeda, S. Kurita, Phys. Rev. Lett., 81, 417 (1998). (c) T. Suemoto, S. Tomimoto, J. Luminescence., 83-94, 13 (1999).

11) M. Yamashita, Y. Nonaka, S. Kida, Y. Hamaue, R. Aoki, Inorg. Chim. Acta, 52, 43 (1981).

12) K. Toriumi, Y. Wada, T. Mitani, S. Bandow, M. Yamashita, Y. Fujii, J. Am. Chem. Soc., 111, 2341 (1989).

13) H. Okamoto, Y. Shimada, Y. Oka, A. Chainani, T. Takahashi, H. Kitagawa, T. Mitani, K. Toriumi, K. Inoue, T. Manabe, M. Yamashita, Phys. Rev. B, 54, 8438 (1996).

14) (a) Okamoto, H.; Mitani, T.; Toriumi, K.; Yamashita, M. Mater. Sci. Eng. B, 13, L9 (1992). (b) Okamoto H.; Mitani, T. Prog. Theor. Phys., 113, 191 (1993).

15) (a) K. Nasu, J. Phys. Soc. Jpn., 52, 3865 (1984). (b) K. Iwano, K. Nasu, J. Phys. Soc. Jpn., 61, 1380 (1992). (c) S. M. WebberMilbrodt, J. T. Gammel, A. R. Bishop, E. Y. Lor, Jr., Phys. Rev. B, 45, 6435 (1992).

16) (a) C. Creutz, H. Taube, J. Am. Chem. Soc., 91, 3988 (1969). (b) C. Creutz, H. Taube, J. Am. Chem. Soc., 95, 1086 (1973).

17) (a) D. E. Richardson, H. Taube, Coord. Chem. Rev., 60, 107 (1984). (b) J. Poppe, M. Moscherosch. W. Kaim, Inorg. Chem. 32, 2640 (1993). (c) D. Yokogawa, H. Sato, Y. Nakao, and S. Sakaki, Inorg. Chem. 46, 1966 (2007).

18) M. B. Robin, P. Day, Adv. Inorg. Radiochem., 10, 247 (1967).
19) H. Okamoto, M. Yamashita, Bull. Chem. Soc. Jpn., 71, 2023 (1998).

20）日本化学会編, 化学便覧改訂 4 版, 丸善, pp. II-726.

21) S. Takaishi, M. Takamura, T. Kajiwara, H. Miyasaka, M. Yamashita, M. Iwata, H. Matsuzaki, H. Okamoto, H. Tanaka, S. Kuroda, H. Nishikawa, H. Oshio, K. Kato, M. Takata, J. Am. Chem. Soc., 130, 12080 (2008).

22) N. Kimizuka, S. H. Lee, T. Kunitake, Angew. Chem. Int. Ed., 39, 389 (2000).

23) H. Okamoto, K. Toriumi, T. Mitani, M. Yamashita, Phys. Rev. B, 42, 10381 (1990).

24) (a) 谷野浩史, 固体物理, 17, 733 (1982). (b) 那須奎一郎, 山下 正廣, 三谷忠興, 栗田進, 日本物理学会誌, 41, 317 (1986).

25) S. Takaishi, H. Miyasaka, K. Sugiura, M. Yamashita, H. Matsuzaki, H. Kishida, H. Okamoto, H. Tanaka, K. Marumoto, H. Ito, S. Kuroda, T. Takami, Angew. Chem. Int. Ed., 43, 3171 (2004).

26) A. Hazell, Acta Cryst. C, 47, 962 (1991).

27) Y. Wakabayashi, N. Wakabayashi, M. Yamashita, T. Manabe, N. Matsushita, Phys. Soc. Jpn., 68, 3948 (1999).

28) (a) T. Manabe, M. Yamashita, T. Kawashima, H. Okamoto, H. Kitagawa, T. Mitani, K. Toriumi, H. Miyamae, K. Inoue, K. Yakushi, Proc. of SPIE, 3145, 106, (1997). (b) T. Manabe, T. Kawashima, M. Yamashita, H. Okamoto, H. Kitagawa, T. Mitani, M. Inokuchi, K. Yakushi, Synth. Met. 86, 2233 (1997).

29) (a) M.Yamashita, T. Ishii, H. Matsuzaka, T. Manabe, T. Kawashima, H. Okamoto, H. Kitagawa, T. Mitani, K. Marumoto, S. Kuroda, Inorg. Chem., 38, 5124 (1999). (b) H. Matsuzaki, K. Iwano, T. Aizawa, M. Ono, H. Kishida, M. Yamashita, H. Okamoto, Phys. Rev. B, 70, 035204 (2004).

30) K. Marumoto, H. Tanaka, S. Kuroda, T. Manabe, M. Yamashita, Phys. Rev. B, 60, 7699 (1999).

31) K. Iwano, J. Phys. Soc. Jpn., 68, 935 (1999).

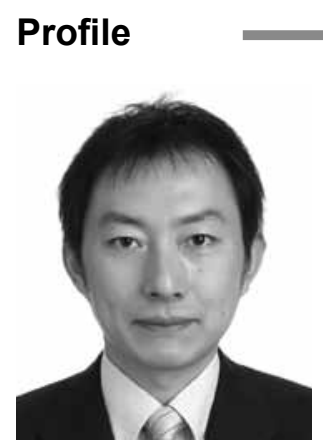

\section{高石＼cjkstart慎也}

東北大学大学院理学研究科助教 博士 (理学)

[ 経歴] 1998 年筑波大学第一学群自然学類卒業、2003 年筑波大学大学院化学研究科博士課 程修了、同年東京都立大学大学院理学研究科博士研究員、2004 年東北大学大学院理学研究科 助手、2006 年より現職。

[ 専門] 錯体化学、固体物性化学、固体NMR 